\title{
The relationship between admission criteria and pre-service teacher preparedness for a small rural educator preparation provider
}

\author{
Gerald Mihelic, Ed.D. \\ Oklahoma Panhandle State University and Oral Roberts University \\ Chancey Bosch, Ph.D. \\ Oral Roberts University College of Education \\ Kim Boyd, Ed.D. \\ Oral Roberts University College of Education \\ Mary Lou Miller, Ed.D. \\ Oral Roberts University College of Education
}

\begin{abstract}
Pre-service teacher preparedness is a measurement of a teacher candidate's ability to become an effective teacher (Clark, Byrnes, \& Sudweeks, 2015). A growing number of Educator Preparation Providers' (EPPs') accrediting agencies are insisting that to improve pre-service teacher preparedness, EPPs must increase the rigor of their admission criteria. However, the research is inconclusive regarding whether a relationship exists between admission criteria and pre-service teacher preparedness. Therefore, the purpose of this study was to investigate the relationship between the Educator Preparation Provider's (EPP's) current teacher education program admission criteria and pre-service teacher preparedness measurements to determine if the EPP should increase its admission criteria.

Multiple linear regression analysis was used to examine the relationship between the three independent variables of admission criteria and the dependent variable of teacher preparedness. Results indicate no significant relationship between admission criteria and teacher preparedness. Findings were used to create a recommendation regarding the EPP's admission criteria to the teacher education program.
\end{abstract}

Keywords: Accreditation, Admission Criteria, Educator Preparation Provider, Regression Analysis, Rural, Teacher Education

\section{Introduction and Problem}

1 n Educator Preparation Provider's (EPP's) mission is to prepare teacher candidates, students in the teacher education program, to be successful classroom teachers (Beare, Marshall, Torgerson, Tracz, \& Chiero, 2012; DeLuca, 2012; Henry, Kershaw, Zulli, \& Smith, 2012; Miller-Levy, Taylor, \& Hawke, 2014). EPP accrediting agencies provide accountability and guidance for successful teacher education programs. For example, the United States Department of Education (USDE) and the Council for Higher Education Accreditation (CHEA) authorized the National Council for the Accreditation of Teacher

MIHELIC, BOSCH, BOYD, \& MILLER / DOI: 10.5929/2019.1.14.3 
Education (NCATE), established in 1954, and the Teacher Education Accreditation Council (TEAC), established in 1997 (Council for the Accreditation of Educator Preparation [CAEP], n.d.; Murray, 2012). In 2013, NCATE and TEAC consolidated into the Council for Accreditation of Educator Preparation (CAEP) to become one accrediting agency for EPPs (CAEP, n.d.; Walsh, 2013). In 2014, CAEP received recognition from CHEA (CAEP, n.d.).

In Oklahoma, admission criteria are within the purview of the Oklahoma State Regents for Higher Education (Oklahoma State Regents for Higher Education [OSRHE], 2016). As the governing body for higher education, the OSHRE establishes state-level teacher education program criteria (OSRHE, 2016). Accreditation by the state, which includes the admission criteria established by the OSRHE, is required for an EPP to recommend a candidate for certification. State accreditation in Oklahoma is a partnership between the Office of Educational Quality and Accountability (OEQA), CAEP, OSRHE, and representatives from EPPs (Office of Educational Quality and Accountability [OEQA], 2018). For this study, EPP accreditation by CAEP is critical because several of the EPP candidates graduate, relocate to bordering states, and need CAEP accreditation for teacher program recognition.

One method to help gain accreditation and accomplish the EPP's mission is to establish rigorous admission criteria for higher education candidates seeking entrance to a teacher education program (DeLuca, 2012; Miller-Levy et al., 2014; Thomson et al., 2011). Admission criteria are used to assess teacher candidate readiness (DeLuca, 2012; Miller-Levy et al., 2014). Specifically, admission criteria are used to identify and screen out potentially ineffective future classroom teachers (DeLuca, 2012; Fuller, 2014; Miller-Levy et al., 2014).

Recently, in preparing for CAEP accreditation, a small rural mid-western EPP examined situational forces creating pressure to increase admission criteria requirements for its Teacher Education Program (TEP). The admission standards for the TEP in this study are:

1. A minimum passing score of $\mathbf{2 4 0}$ on the Oklahoma General Education Test (OGET)

2. A minimum higher education cumulative grade point average (GPA) of 2.5

3. A passing score on a disposition instrument (Oklahoma Panhandle State University [OPSU], 2016).

Increasing admission criteria is problematic for several reasons. First, the rural EPP operates within an open-enrollment university with a high number of first-generation college students (Oklahoma Panhandle State University [OPSU], 2017). Second, the EPP prepares teacher candidates, many of whom, accept positions in surrounding underserved communities (OPSU, 2017). Third, the EPP is experiencing a declining enrollment of teacher education candidates-16\% during the 2016-2017 school year and a projected decline of 22\% for the 2018-2019 school year (OPSU, 2017). CAEP Standard 3, Elements 3.2 and 3.3 address admission criteria based on GPA, nationally normed test scores, and dispositions (CAEP, 2016). Therefore, in an effort to increase teacher candidate preparedness, some higher education stakeholders are advocating for an increase in admission criteria to the TEP. Opponents of an increase of admission criteria fear a further decline, resulting in the EPP closing or changing its operation model from a traditional certification program to an alternative certification program.

Rural communities depend on local EPPs to produce their teacher force (Barley, 2009). In addition, rural EPPs are an asset to rural school districts with an underserved population and shortage of teacher education graduates (Barley, 2009). In part due to the elimination of 480 teaching positions, Oklahoma public schools began the 2017 school year with 536 classrooms lacking certified teachers despite issuing 1,430 emergency teaching certificates (Oklahoma State School Boards Association, 2017). In 2016, the

MIHELIC, BOSCH, BOYD, \& MILLER / DOI: 10.5929/2019.1.14.3 
largest school district in the EPP's area reported hiring nearly 30 emergency certified teachers with little to no teacher education training. The same school district replaced $15 \%$, or approximately 30 to 40 teachers every year. A study completed in North Dakota on teacher retention found that while new teachers who had completed programs in urban EPPs did, in fact, return to their rural communities to begin their teaching careers, 78\% percent left after one year (Harris, Holdman, Clark, \& Harris, 2005). Consequently, rural communities are in dire need of effectively prepared teacher candidates from rural institutions who are committed to remaining in the area.

According to Burton and Johnson (2010), pre-service teacher programs need institutions with relationships in rural communities to prepare candidates for teaching in rural schools. Rural communities depend on these EPPs to supply the majority of their teacher workforce (Barley, 2009). The small midwestern rural EPP in this study provides the surrounding school districts with a large percentage of its teacher workforce. For example, during the 2016 school year, $60 \%$ of the teachers employed in the EPP's county's largest school district were graduates from that institution (OPSU, 2017). Furthermore, the EPP is the only state institution that offers a bachelor's degree in teacher education within 180 miles (OPSU, 2017). Examination of research addressing teacher education programs in rural communities is necessary to adequately address the educational needs of the community and accreditation needs of the EPP (Barley, 2009).

A review of research examining the admission criteria of teacher education programs (TEP) reveals a gap. Research addressing a positive correlation between TEP admission criteria and pre-service teacher preparedness is inconclusive (Deluca, 2012). Researchers have recommended further studies to examine if a relationship exists between the teacher preparation admission criteria and pre-service teacher preparedness (Cochran-Smith \& Villegas, 2015; Fuller, 2014; Miller-Levy et al., 2014). Determining if such a relationship exists is critical to the EPP's ability to continue its current practice of operating within the open enrollment policy of the institution.

According to Webb-Sunderhaus (2010), open enrollment refers to admission to an institution of higher education not based on traditional academic metrics, such as standardized college entrance exams or grade point average. Higher education institutions with open enrollment policies provide opportunities for candidates who do not meet the more stringent admission criteria of other higher education institutions (Educational Partnerships, Inc., 2012; Webb-Sunderhaus, 2010). Researchers for The National Center for Educational Statistics (2017) report, of the 2,584 bachelor's degree-granting institutions in the United States, $28 \%$ use open enrollment admission policies. In Oklahoma, 24 higher education institutions use open enrollment or alternative enrollment policies (CollegeCalc, 2017). Half of the 24 Oklahoma institutions with open enrollment or alternative enrollment policies offer teacher education programs. Of those, 10 are currently working to meet the new CAEP accreditation standards. As such, CAEP Standard 3.2 could pose serious challenges. Therefore, the need to investigate the relationship between teacher education program admission criteria and pre-service teacher preparedness measurements is essential for higher education institutions. Effective pre-service teachers, measured through teacher preparedness, possess the ability and skills to be effective teachers (Clark, Byrnes, \& Sudweeks, 2015).

\section{Review of Literature}

The purpose of admission criteria for an Educator Preparation Provider (EPP) is to help select teacher candidates who will be successful as classroom educators (Casey \& Childs, 2011). According to MillerLevy et al. (2014), admission criteria are the first benchmark to prevent potentially ineffective teachers from entering teacher education programs. Three common admission criteria used by EPPs to determine

MIHELIC, BOSCH, BOYD, \& MILLER / DOI: 10.5929/2019.1.14.3 
entry into teacher education programs include candidate dispositions, grade point average (GPA), and standardized test scores (Deluca, 2012).

Recent political pressures from politicians and policymakers have motivated EPP accrediting agencies to increase the rigor of admission criteria and accreditation standards (Cochran-Smith \& Villegas, 2015). The American Federation of Teachers (2013) also supported more rigorous admission criteria, with the intention of increasing the effectiveness of pre-service and classroom teachers. However, there is little evidence that suggests raising admission criteria will result in increased pre-service teacher preparedness or teacher quality (Dee \& Morton, 2016; Fuller, 2014). Comprehensively, the research regarding a positive relationship between admission criterion and pre-service teacher preparedness measurements is conflicting.

Choi, Benson, and Shudak (2016) reported finding no significant relationship between candidate dispositions and teacher preparedness measurements. However, other researchers indicate there is a strong relationship between candidate dispositions and teacher preparedness. Robertson-Kraft and Duckworth (2014) reported novice teacher success and effectiveness are directly related to teacher candidate disposition, not academic variables. Researchers concluded that candidate dispositions are critical to pre-service teacher effectiveness (Duckworth \& Yeager, 2015; Hochstetler, 2014).

In addition to the candidate's disposition, research has specifically reported academic measures, such as GPA and standardized tests, as predictors of pre-service teacher effectiveness (Casey \& Childs, 2011; Hall \& West, 2011; Henry et al., 2013). Henry et al. (2013) reported GPA as a better predictor of pre-service teacher preparedness than any other admission criterion. In contrast, Hall and West (2011) reported evidence of a limited relationship between GPA and pre-service teacher preparedness. Dee and Morton (2016) also reported no significant difference between pre-service teacher preparedness for candidates who entered a TEP with a GPA above 3.0 and those who entered the TEP with a GPA below 3.0, suggesting GPA is not a predictor of pre-service teacher preparedness.

Standardized test scores, the third most common teacher education admittance criterion, are reported as having a positive relationship with the candidate's GPA (Fuller, 2014). However, evidence from the same study did not suggest standardized test scores predicted pre-service teacher preparedness (Fuller, 2014). In contrast, Hall and West (2011) reported evidence of a relationship between test scores and preservice teacher preparedness when connected to standardized test scores of subject-area content knowledge. There is some evidence that higher standardized test scores, together with a minimum GPA of 3.0, are predictors of effective pre-service teacher preparedness (American Federation of Teachers, 2013; Greenberg, McKee, \& Walsh, 2013).

The evidence regarding the relationship between teacher education program admission criteria and preservice teacher preparedness is complex (Cochran-Smith \& Villegas, 2015; Miller-Levy et al., 2014). There is conflicting evidence in the literature regarding the relationship of admission criteria and pre-service teacher preparedness measurements. Additionally, there is not a consensus among researchers regarding which admission criteria is a better predictor of higher pre-service teacher preparedness measurements. Henry et al. (2013) recommended an urgent need to develop reliable and valid measures that predict pre-service teacher preparedness. Admission criteria used by EPPs for entry into professional education programs must be supported by evidence-based research that they are accurate predictors of pre-service teacher preparedness (Fuller, 2014).

MIHELIC, BOSCH, BOYD, \& MILLER / DOI: 10.5929/2019.1.14.3 


\section{Methodology}

The purpose of this study was to examine the relationship between the admission criteria of the EPP'S TEP and pre-service teacher preparedness measurements. The admission criteria to the EPP's TEP in this study include the candidate's GPA, the Oklahoma General Education Test (OGET) score, and a disposition measurement. Pre-service teacher preparedness was determined using a composite score from the Student Teacher Evaluation instrument (STE) and Teacher Work Sample (TWS). The EPP policy for acceptance to the TEP requires a minimum score of 3.0 on the STE and a minimum score of 2.0 on the TWS. Therefore, although a limitation of the study design, a composite score provided a variable for measuring teacher preparedness.

The research questions for this study were:

1. Which of the EPP's Teacher Education Program (TEP) admission criteria are statistically significant in predicting pre-service teacher preparedness?

2. Which TEP admission criteria value is statistically significant in predicting pre-service teacher preparedness?

This study used a multiple regression analysis to answer the research questions. Multiple regression analysis determines if a relationship exists between two or more variables (Gay, Mills, \& Airasian, 2012; Laerd Statistics, 2015). In addition, multiple regression analysis helps to identify the degree to which the independent variables predict the dependent variable while controlling the independent variables in relation to the dependent variable (Gay et al., 2012; Urdan, 2017; Laerd Statistics, 2015). Many published studies use multiple regression analysis because of the powerful information gained through the associations between the independent variables and the dependent variable (Urdan, 2017).

Three independent variables from the EPP'S TEP admission criteria were considered for the multiple regression analysis. The criteria included the candidate's GPA, OGET composite score, and disposition score. The GPA used in the study is the candidate's higher education cumulative GPA. The OGET score used in the study is the composite score from the six sub-areas assessing a candidate's general education and critical thinking knowledge (OEQA, 2018). The disposition instrument is measured using a rubric. It is scored by three faculty members of the candidate's choice and is reported using the average of the three faculty member's individual scores. At the time of the EPP's accreditation, all EPP-created assessments were required to be evaluated by CAEP using the Evaluation Framework for EPP-Created Assessments rubric. The EPP submitted several assessment instruments to be evaluated including the disposition instrument. It was determined that the instrument was at the CAEP Sufficient Level.

The dependent variable for the study was the composite pre-service teacher preparedness score, calculated by adding the final score of the candidate's Student Teacher Evaluation (STE) and the Teacher Work Sample (TWS). The STE and the TWS are measures of pre-service teacher preparedness (Caughlan \& Jiang, 2014; La Paro et al., 2014; Watkins \& Watkins, 2011). These instruments were evaluated by CAEP using the Evaluation Framework for EPP-created assessment and found to be at the CAEP Sufficient Level.

The Teacher and Leader Effectiveness (TLE) Observation and Evaluation System is an evidence-based process of teacher evaluation, feedback, and support anchored in specific domains, dimensions, and indicators reflecting national best practices and current research regarding effective instruction. Administrators using the TLE rubric evaluate teachers on all indicators. Ratings are 1 - Ineffective, 2 Needs Improvement, 3 - Effective, 4 - Highly Effective, and 5 -Superior. Scores of 3, 4, and 5 indicate that performance meets expectations (Tulsa Public Schools, n.d.).

MIHELIC, BOSCH, BOYD, \& MILLER / DOI: 10.5929/2019.1.14.3 
The EPP uses Domain 1 (Classroom Management) and Domain 2 (Instructional Effectiveness) of the Tulsa Model Teacher and Leader Effectiveness (TLE) Observation and Evaluation System for its student-teacher evaluation. Because the EPP altered the components of TLE evaluation instrument by using only two of the domains and redefined the audience in which the instrument was intended, it was categorized as an EPP-Created Assessment. It, therefore, was subjected to the CAEP Evaluation Framework for EPP-Created Assessments process as described for the disposition instrument. The revised TLE student teacher evaluation instrument was found to be at the CAEP Sufficient Level.

The study population included all program completers between 2013 and 2016 . A convenience sample of all 49 program completers was used because data were available for both admission criteria and teacher preparedness. The study population included candidates majoring in Math, English, Elementary, Music, Agriculture, and Physical Education programs. This procedure and sample size met the requirements for a multiple regression analysis with a medium effect size (Gay et al., 2012; Tuckman \& Harper, 2012).

The Statistical Package for Social Science (SPSS) software was used to check the following eight assumptions of a multiple regression analysis:

1. All dependent variables measured at a continuous level.

2. More than two independent variables measured at a continuous level.

3. Independence of observations or residuals was verified with a Durbin-Watson statistic of 2.003 for each independent variable.

4. A linear relationship existed between the dependent and independent variables.

5. Homoscedasticity was verified using visual inspection of a plot of standardized residuals versus standardized predicted values.

6. The variance inflation factor (VIF) values of 1.164 for OGET, 1.179 for GPA, and 1.083 for the dispositional measurement showed no multicollinearity.

7. A visual inspection of a scatterplot and casewise diagnostics established linearity with no outliers.

8. A visual inspection of a normal probability plot established normally distributed residuals (Laerd Statistics, 2015).

After meeting the assumptions for multiple regression analysis, SPSS was used to determine the line of best fit with a .05 alpha level, which is the standard in educational research (Gay et al., 2012). The line of best fit describes the best predictive value between the independent variables and the dependent variable (Gravetter \& Wallnau, 2013). The equation for the line of best fit for the multiple regression was $\hat{Y}=b_{1} X_{1}+b_{2} X_{2}+b_{3} X_{3}+a$ (Gravetter \& Wallnau, 2013; Urdan, 2017). In the equation, $\hat{Y}$ represents the composite pre-service teacher preparedness score (dependent variable), $X_{1}$ represents the OGET (independent variable), $X_{2}$ represents GPA (independent variable), and $X_{3}$ represents the dispositional measurement (independent variable). The letter $b$ represents the slope of the regression line for each of the independent variables. The letter $a$ represents the $y$-intercept of the regression line (Gravetter \& Wallnau, 2013; Laerd Statistics, 2015).

The first question of the existence of a significant relationship is answered using the Pearson Correlation and variance explained by the Pearson Correlation (Urdan, 2017). The second research question of the value of the predictive relationship is answered by the value of $\hat{Y}$ (Leard Statistics, 2015; Urdan, 2017).

MIHELIC, BOSCH, BOYD, \& MILLER / DOI: 10.5929/2019.1.14.3 


\section{Results and Findings}

The SPSS was used to determine a "good fit" of the data for the multiple regression model (Gravetter \& Wallnau, 2013; Laerd Statistics, 2015). A "good fit" is determined using the Pearson's $r$, the analysis of the Analysis of Variance (ANOVA), and the variance's Model Summary (Laerd Statistics, 2015; Urdan 2017). This process begins with an analysis of descriptive statistics including the mean, standard deviation, and sample size (see Table 1).

Table 1

Descriptive Statistics

\begin{tabular}{lccc}
\hline Variables & Mean & Std. Deviation & N \\
\hline $\begin{array}{l}\text { Dependent variable } \\
\quad \text { Comp Score }\end{array}$ & 5.664 & & 49 \\
$\quad$ Independent variables & & .413 & \\
OGET & 260.67 & 14.456 & 49 \\
GPA & 3.083 & .431 & 49 \\
Disposition & 2.599 & .280 & 49 \\
\hline
\end{tabular}

Note. The OGET had the largest standard deviation.

Second, a Pearson's $r$ was computed to assess the relationship between the three independent variables and the dependent variable. A strong correlation of variables is close to $+/-1.00$ (Gravetter \& Wallnau, 2013). Table 2 and Table 3 indicate no significant correlation between the OGET and the composite preservice teacher preparedness score $(r=-.054, n=49, p=.357)$, no correlation between GPA and the composite pre-service teacher preparedness score $(r=.130, n=49, p=.187)$, and no correlation between the disposition measure and the composite pre-service teacher preparedness score $(r=.180, n=49, p=$ .108).

Table 2

Pearson Correlation

\begin{tabular}{lcccc}
\hline Variables & Comp & OGET & GPA & Disposition \\
\hline Comp & 1.000 & -0.54 & .130 & .180 \\
OGET & -.054 & 1.000 & .351 & .231 \\
GPA & .130 & .351 & 1.000 & .240 \\
Disposition & .180 & .213 & .240 & 1.000 \\
\hline
\end{tabular}

Note. The dependent variable is the composite pre-service teacher preparedness score. 
Table 3

Sig. (1-tailed)

\begin{tabular}{lcccc}
\hline Variables & Comp & OGET & GPA & Disposition \\
\hline Comp & & .357 & .187 & .108 \\
OGET & .357 & & .007 & .071 \\
GPA & .187 & .007 & & .048 \\
Disposition & .108 & .071 & .048 & \\
\hline
\end{tabular}

Note. The only two correlations were between the GPA and the OGET and the GPA and the Disposition.

Third, the variance between the variables was analyzed using the Pearson's $\mathrm{r}$. The $R$-value measures the correlation between the variables, the R-squared $\left(R^{2}\right)$ value measures the variance in the dependent variable as explained by the independent variables, and the $R^{2}$ adjusted measures the value expected for the population (Laerd Statistics, 2015; Urdan, 2017). Table 4 reports $R^{2}$ for the overall model was $5.7 \%$ with an adjusted $R^{2}$ of $-0.6 \%$. This size effect is not statistically significant, which means the independent variables explain a very low percentage of the variance in the dependent variable (Urdan, 2017).

Table 4

Model of Summary

\begin{tabular}{cccccc}
\hline Model & $\mathrm{R}$ & $\mathrm{R}^{2}$ & Adjusted $\mathrm{R}^{2}$ & $\begin{array}{c}\text { Std. Error } \\
\text { of the Estimate }\end{array}$ & Durbin-Watson \\
\hline 1 & .238 & .057 & -.006 & .41446 & 2.003 \\
\hline
\end{tabular}

Note. The dependent variable is the composite pre-service teacher preparedness score.

Fourth, the next test of fitness for the regression was to measure the statistical significance with the ANOVA (Laerd Statistics, 2015). The ANOVA reports a value of predicted power and clarifies if the variance explained in the Pearson correlation is significant (Laerd Statistics, 2015; Urdan, 2017). Table 5 reports the independent variables (OGET, GPA, and Disposition) are not statistically significant predictors of preservice teacher effectiveness, $\mathrm{F}(3,45)=.904, p=.447$. Therefore, even though the assumptions were met and the data were linear, there was not a good fit of a model for multiple regression.

Table 5

ANOVA Summary of Model for Multiple Regression

\begin{tabular}{lccccc}
\hline Model & SS & df & MS & F & Sig. \\
\hline Regression & .466 & 3 & .155 & .904 & .447 \\
Residual & 7.730 & 45 & .172 & & \\
Total & 8.195 & 48 & & & \\
\hline
\end{tabular}

Note. The dependent variable is the composite pre-service teacher preparedness score.

Tables 2 through 5 support the response to the first research question, which shows no statistically significant relationship between the EPP's Teacher Education Program admission criteria and pre-service teacher preparedness. Table 6 supports the response to the second research question by showing the investigation of the coefficients. The coefficients help determine the slope, intercept, and significance for each regression line (Gay et al., 2012; Laerd Statistics, 2015). Table 6 indicates the slope for the OGET is not statistically significant, $t=-0.890, p>.05$, the slope for the GPA is not statistically significant, $t=0.865$, $p>.05$, and the disposition measurement is not statistically significant, $t=1.172, p>.05$.

MIHELIC, BOSCH, BOYD, \& MILLER / DOI: 10.5929/2019.1.14.3 
Table 6

Coefficients for the Multiple Regression

\begin{tabular}{|c|c|c|c|c|c|}
\hline & Unstandardized & & Standardized & & \\
\hline & B & SE & Beta & $\mathrm{t}$ & Sig. \\
\hline (Constant) & 5.620 & 1.131 & & 4.970 & .000 \\
\hline OGET & -.004 & .004 & -.139 & -.890 & .378 \\
\hline GPA & .130 & .151 & .136 & .865 & .392 \\
\hline Disposition & .261 & .223 & .177 & 1.172 & .247 \\
\hline
\end{tabular}

Note. The dependent variable is the composite pre-service teacher preparedness score. The independent variables are OGET, GPA, and Disposition.

Overall, the findings report no statistically significant relationships between the pre-service teacher preparedness measurements and the EPP's Teacher Education Program admission criteria. Furthermore, none of the coefficients in the regression equation significantly accounted for the change in the composite pre-service preparedness score. Thus, the regression model did not successfully predict the dependent variable (Gravetter \& Wallnau, 2013).

There are limitations to this study. The small sample size does not allow for demographic analysis including gender, program of study, or first-generation college students. Finally, the small sample size limits generalizability.

\section{Discussion and Implications}

According to Arbaugh, Ball, Grossman, Heller, and Monk (2015), educational leaders are paramount in designing effective teacher education programs. Educational leaders are charged with the responsibility to produce highly qualified and effective teacher candidates through pre-service teacher preparation programs (Dee \& Morton, 2016; Henry et al., 2012; Miller-Levy et al., 2014). Furthermore, educational leaders in EPPs are obligated professionally and morally to be accountable for producing prepared preservice teachers by designing and implementing an excellent teacher education program (Arbaugh et al., 2015).

Admission requirements play a significant role in an EPP's ability to produce highly qualified and effective teachers through pre-service teacher preparation programs and accreditation (Dee \& Morton, 2016; DeLuca, 2012; Fuller, 2014; Miller-Levy et al., 2014). Educational leaders must ensure teacher education program admission criteria are established to assist in the early identification of teacher candidates who can be effective classroom teachers (Dee \& Morton, 2016; Miller-Levy et al., 2014). Research must be used to establish specific admission criteria to help predict pre-service teacher preparedness (Arbaugh et al., 2015, Dee \& Morton, 2016). Also, CAEP Standard 3; elements 3.2 and 3.3 mandate specific admission criteria for teacher education programs for accreditation.

This study supports the findings by Choi et al. (2016), Dee and Morton (2016), and Fuller (2014), that there is not a significant relationship or predictive value between admission criteria to teacher education programs and the outcomes. The lack of any significant relationship between the OGET, GPA, and EPP disposition, coupled with the lack of significant predictive value of the OGET, GPA, and EPP disposition, suggests that the EPP should recommend it maintain its current admission criteria. However, this must be done with caution, as they are required to address annually whether the EPP continues to meet the CAEP Standards.

MIHELIC, BOSCH, BOYD, \& MILLER / DOI: 10.5929/2019.1.14.3 


\section{Conclusion}

An EPP's admission criteria to the teacher education program needs to help in selecting and producing highly qualified and effective teacher candidates (Deluca, 2012; Hall \& West, 2011; Miller-Levy et al., 2014). There is conflicting research regarding which measures of admission criterion correlate to preservice teacher preparedness (Dee \& Morton, 2016). Admission criteria to a teacher education program must be researched to determine which criteria correlates to a candidate's ability to become an effective classroom teacher (Cochran-Smith \& Villegas, 2015; Dee \& Morton, 2016; Thomson et al., 2011).

Each EPP needs to research the relationship between its admission criteria to the teacher education program and pre-service teacher preparedness (Dee \& Morton, 2016; Miller-Levy et al., 2014). EPPs need research to determine which admission criterion, and its predictive value of teacher preparedness, are best (Dee \& Morton, 2016; DeLuca, 2012; Miller-Levy et al., 2014). For the EPP in this study, the current admission criteria aid in the selection of higher education students preparing to become teacher candidates. Because there was no significant relationship between each criterion and pre-service teacher preparedness, the EPP will continue using the current TEP admission criteria. The EPP administrators should continue to collect data and reexamine the admission criteria with a larger sample of candidates.

\section{References}

American Federation of Teachers. (2013). Raising the bar: Aligning and elevating teacher preparation and the teaching profession. Retrieved from http://www.aft.org/sites/default/files/news/raisingthebar2013.pdf

Arbaugh, F., Ball, D. L., Grossman, P., Heller, D. E., \& Monk, D. (2015). Deans' corner: Views on the state of teacher education in 2015. Journal of Teacher Education, 66(5), 435-445. doi:10.1177/0022487115602314

Barley, Z. A. (2009). Preparing teachers for rural appointments: Lesson from the mid-continent. The Rural Educator, 30(3), 10-15.

Beare, P., Marshall, J., Torgerson, C., Tracz, S., \& Chiero, R. (2012). Toward a culture of evidence: Factors affecting survey assessments of teacher preparation. Teacher Education Quarterly, 39(1), 159173.

Burton, M., \& Johnson, A. S. (2010). "Where else would we teach?": Portraits of two teachers in the rural south. Journal of Teacher Education, 61(4), 376-386. doi:10.1177/0022487110372362

Casey, C., \& Childs, R. (2011). Teacher education admission criteria as measure of preparedness for teaching. Canadian Journal of Education, 34(2), 3-20.

Caughlan, S., \& Jiang, H. (2014). Observation and teacher quality: Critical analysis of observational instruments in preservice teacher performance assessments. Journal of Teacher Education, 65(5), 375-388. doi:10.1177/0022487114541546

CollegeCalc. (2017). Oklahoma open admissions colleges, cost and affordability for 2016. Retrieved from http://www.collegecalc.org/colleges/oklahoma/open-admissions/

Choi, H., Benson, N. F., \& Shudak, N. J. (2016). Assessment of teacher candidate dispositions: Evidence of reliability and validity. Teacher Education Quarterly, 43(3), 71-89.

MIHELIC, BOSCH, BOYD, \& MILLER / DOI: 10.5929/2019.1.14.3 
Clark, S. K., Byrnes, D., \& Sudweeks, R. R. (2015). A comparative examination of student teacher and intern perceptions of teaching ability at preservice and inservice stages. Journal of Teacher Education, 66(2), 170-183. doi:10.1177/0022487114561659

Cochran-Smith, M., \& Villegas, A. M. (2015). Framing teacher preparation research: An overview of the field, part I. Journal of Teacher Education, 66(1), 7-20. doi:10.1177/002248711459072

Council for the Accreditation of Educator Preparation. (2016). CAEP accreditation handbook. Retrieved from http://www.caepnet.org/

Council for the Accreditation of Educator Preparation. (n.d.). History of CAEP. Retrieved from http://www.caepnet.org/

Dee, A. L., \& Morton, B. M. (2016). Admissions metrics: A red herring in educator preparation? Issues in Teacher Education, 25(1), 73-89.

DeLuca, C. (2012). Selecting inclusive teacher candidates: Validity and reliability issues in admission policy and practice. Teacher Education Quarterly, 38(4), 7-31. Retrieved from http://www.jstor.org/journal/teaceducquar

Duckworth, A. L., \& Yeager, D. C. (2015). Measurement matters: Assessing personal qualities other than cognitive ability for educational purpose. Educational Researcher, 44(4), 237-251. doi:10.3102/0013189X15584327

Educational Partnerships, Inc. (2012). Research Brief: College prep skills development programs for high school students and college and universities using alternative admissions criteria and providing support for students with academic needs. Retrieved from https://files.eric.ed.gov/fulltext/ED537944.pdf

Fuller, E. J. (2014). Shaky methods, shaky motives: A critique of the National Council of Teacher Quality's review of teacher preparation programs. Journal of Teacher Education, 65(1), 63-77. doi:10.1177/0022487113503872

Gay, L. R., Mills, G. E., \& Airasian, P. (2012). Educational research: Competencies for analysis and applications (10th ed.). Boston, MA: Pearson Education.

Gravetter, F. J., \& Wallnau, L. B. (2013). Statistics for the behavioral sciences (9th ed.). Belmont, CA: Wadsworth.

Greenberg, J., McKee, A., \& Walsh, K. (2013). Teacher prep review: A review of the nation's teacher preparation programs. Washington D.C.: National Council of Teacher Quality

Hall, P. C., \& West, J. H. (2011). Potential predictors of student teaching performance: Considering emotional intelligence. Issues in Educational Research, 21(2), 145-161. Retrieved from http://iier.org.au/iier21/hall.pdf

Harris, M. M., Holdman, L., Clark, R., \& Harris, T. R. (2005). Rural teachers in Project Launch. The Rural Educator, 26(2), 23-32. Retrieved from http://www.nrea.net/The Rural Educator

Henry, G. T., Campbell, S. L., Thompson, C. T., Patriarca, L. A., Luterbach, K. J., Lys, D. B., \& Covington, V. M. (2013). The predictive validity of measures of teacher candidates programs and performance: Toward an evidence-based approach to teacher preparation. Journal of Teacher Education, 64(5), 439-453. doi:10.1177/0022487113496431

MIHELIC, BOSCH, BOYD, \& MILLER / DOI: 10.5929/2019.1.14.3 
Henry, G. T., Kershaw, D. C., Zulli, R. A., \& Smith, A. A. (2012). Incorporating teacher effectiveness into teacher preparation program evaluation. Journal of Teacher Education, 63(5), 335-355. doi:10.1177/0022487112454437

Hochstetler, S. (2014). The critical role of dispositions: What's missing in measurement of English teacher candidate effectiveness. The Clearing House, 87, 9-14. doi:10.1080/00098655.2013.813433

La Paro, K. M., Scott-Little, C., Ejimofor, A., Sumrall, T., Kintner-Duffy, V. L., Pianta, R. C., ... Howes, C. (2014). Student teaching feedback and evaluation: Results from a seven-state survey. Journal of Early Childhood Teacher Education, 35(4), 318-336. doi:10.1080/10901027.2014.968297

Laerd Statistics. (2015). Statistical tutorials and software guides. Retrieved from https://statistics.laerd.com/premium/index.php

Miller-Levy, R., Taylor, D., \& Hawke, L. (2014). Maintaining the boundaries: Teacher preparation program admission criteria for screening quality candidates. Administrative Issues Journal: Connecting Education, Practice, And Research, 4(1), 40-49. Retrieved from http://www.swosu.edu/academics/aij/2014/v4i1/miller-taylor-hawke.pdf

Murray, F. B. (2012, June 29). Six misconceptions about accreditation in higher education: Lessons from teacher education. Change: The Magazine of Higher Learning, 44(4), 52-58. doi:10.1080/00091383.2012.691866

National Center for Educational Statistics. (2017). Characteristics of degree-granting postsecondary institutions. Retrieved from https://nces.ed.gov/programs/coe/indicator_csa.asp

Office of Educational Quality and Accountability. (2018). Retrieved from https://www.ok.gov/oega/

Oklahoma Panhandle State University. (2016). OPSU teacher education portfolio handbook. Retrieved from http://www.opsu.edu/

Oklahoma Panhandle State University. (2017, January 25). Teacher Education Council. Oklahoma Panhandle State EPP Archives, Goodwell, OK.

Oklahoma State Regents for Higher Education. (2016). Chapter 3 - Academic Affairs [Policy and procedures]. Retrieved from http://www.okhighered.org/state-system/policyprocedures/2014/2014-Policy\%20chapter\%203.pdf

Oklahoma State School Boards Association. (2017). Oklahoma's teacher shortage deepens. Retrieved from https://www.ossba.org/2017/08/22/oklahomas-teacher-shortage-deepens/

Robertson-Kraft, C., \& Duckworth, A. L. (2014). True grit: Trait-level perseverance and passion for longterm goals predicts effectiveness and retention among novice teachers. Teachers College Record, 116(3), 1-39. Retrieved from http://www.tcrecord.org/content.asp?contentid=17352

Tulsa Public Schools. (n.d.). About the district. Retrieved from http://www.tulsaschools.org/4 About District/employee standards main.asp

Thomson, D., Cummings, E., Ferguson, A. K., Moizumi, E. M., Sher, Y., Wang, X., ... Childs, R. A. (2011). A role for research in initial teacher education admissions: A case study from one Canadian university. Canadian Journal of Educational Administration and Policy, (121), 1-23.

Tuckman, B. W., \& Harper, B. E. (2012). Conducting educational research (6th ed.). Lanham, MD: Rowman and Littlefield.

MIHELIC, BOSCH, BOYD, \& MILLER / DOI: 10.5929/2019.1.14.3 
Urdan, T. C. (2017). Statistics in plain English (4th ed.). New York, NY: Routledge.

Walsh, K. (2013, Summer). Ed schools don't give teachers the tools they need. Education Next, 13(3), 18-24.

Watkins, P., \& Watkins, S. (2011, Summer). Predictors of teacher candidate success in developing a capstone project: The Teacher Work Sampling (TWS) methodology. Critical Questions in Education, 2(2), 84-92.

Webb-Sunderhaus, S. (2010). When access is not enough: Retaining basic writers at an open-admission university. Journal of Basic Writing, 29(2), 97-116.

About the Authors

Gerald Mihelic (imihelic@opsu.edu) is an assistant professor, department chair of Elementary Education, and director of teach education of Oklahoma Panhandle State University School of Education. He has 27 years of experience in public and higher education. He currently teaches undergraduate courses in teacher preparation.

Chancey Bosch (cbosch@oru.edu) is an assistant professor of curriculum and instruction, and undergraduate chair at Oral Roberts University. He has 20 years of diverse experience teaching and leading in the public and private sector. He currently teaches graduate level courses in education.

Kim Boyd (kboyd@oru.edu) is an associate professor and dean of Oral Roberts University College of Education. She has 35 years of experience in public and higher education.

Mary Lou Miller (mmiller@oru.edu) is a professor at Oral Roberts University. She has 32 years of experience in public and higher education. She currently teaches graduate level courses in education. 